\title{
ISPANŲ KALBA KAIP ANTROJI UŽSIENIO KALBA, JOS REIKŠMĖ IR SVARBA JŪROS KONTEKSTE
}

\author{
Aleksas Eugenijus Kulvietis \\ Lietuvos aukštoji jūreivystès mokykla
}

\begin{abstract}
Anotacija. Pastaruosius 15 metu galima stebèti, kaip Lietuvoje auga susidomèjimas ispanu kalba ne tik universitetuose ir aukštosiose mokyklose, bet pagrindinèse mokyklose ir gimnazijose. Ispanu kalba šiu laiku pasaulyje užima vis tvirtesnes pozicijas. Pagal kalbančiujų skaičiu ispany kalba yra antra ir siekia apie penkis šimtus milijonu gyventojų. 21 valstybejje ši kalba yra pripažinta valstybine kalba, ja kalbama penkiuose vandenynuose. Ispany kalba paplitusi ne tik geografineje, bet ir virtualioje erdvejje. Daug kas teigia, kad yra graži ir lengva kalba, kiti labiau mano, kad verta jos išmokti dèl to, kad per ja galima susipažinti su didžiule kultūrine ir egzotine teritorija.

Šiame straipsnyje bandoma atskleisti naujausius statistinius duomenis apie ispany kalba ir jos ekspansiją. Norima iliustruoti, kokios kalbos politikos dominuoja ir kokia įtaka ispanu kalba daro globaliame pasaulyje. Ar ispanu kalbos mokymo populiarejjimas susijęs su pasaulinemis tendencijomis, turint omenyje, kad dabar šios kalbos pasaulyje mokosi apie 22 milijonai studentų? Ar yra vèlyvosios mados bangos rezultatas? Taip pat iškyla klausimas, kaip pasauli užvaldo anglu kalba: visose socialinése, politinèse ir ekonominèse sferose bendradarbiavimas siejamas su anglu kalba ir jos terminologija, kaip per naujas technologijas ir komunikacijos medijas plinta angliška kultūra, kuri imponuoja ir diktuoja taip ar taip mokèti kalbèti ir prisijungti prie tam tikru standartu, ir ar vis dèl to ispanu kalba išlieka reikalinga ir turi rimta prasmę, kad būtu išmokstama. Tapačiu principu bus analizuojamas ir diskutuojamas ispanu kalbos mokejjimo ir mokymo visu profesiju, kurios susijusios su transportu, prekyba ir jūra, studentams reikalingumas. Galiausiai, bus ieškoma atsakymo i pagrindinị ir motyvuota klausimą: ar yra jūreiviams privaloma kalbèti ispaniškai? Ar tai prestižo reikalas? Ar ispany kalba yra traktuojama kaip tarptautiné jürine kalba? Ir apie tai, ar pastarasis teiginys yra tiesa.
\end{abstract}

Pagrindiniai žodžiai: mokymas, ispanų k., antroji užsienio kalba, daugiakalbystè, tarptautine kalba. 


\section{Ivadas}

Lietuvos geostrateginè vieta, įskaitant jos uostą, galima sakyti, sąlygoja ypatingą situaciją, kokią turi tikrai ne visos valstybès. Kiekviena jūrinè valstybė stengiasi vystyti jūrų laivybą, modernizuoti uostus. (Puidokas, Andriuškaitè, 2012) Palanki geografinè padètis skatina ir toliau modernizuoti Klaipèdos uostą, plèsti krovos ir gabenimo apimtis. Atsižvelgiant ị tai, kontaktas su kitomis kultūromis ir, žinoma, kalbomis yra prioritetinis, kaip ir globali komunikacija. Diskursas apie reliatyvią kalbų svarbą pateikia skaičius, kurie nèra tik šiaip ịspūdingi skaičiai, tai skaičiai, turintys tiesiogines sąsajas su globalizacijos fenomeno poveikiu kultūrai, naujų komunikacijos technologijų atsiradimui ir paplitimui, nevienodam darbo rinkos sutelkimui ir pasiskirstymui, taip pat migracijų srautams. Visa tai prasidejo didžiuosiuose miestuose (metropolinèse erdvėse) kaip fenomenas, išsirutuliojęs iš lingvistinès superivaairovès kaip multimodali komunikacijos forma (Blommaert, 2010). Ir tuo pačiu laiku padejjo, sustiprino ir paskatino internacionalinių kalbų paplitimą ịvairesniuose kontekstuose, tokiuose kaip ekonominiai terminai, tapę neatsiejama tarptautinès rinkos dalimi, jos akivaizdžiu komunikacijos instrumentu. Globalizacijos sociolingvistika, sutelkta daugiau ị paradigmą ,mobilumas“, nei i - „sklaida“, taip pat paliko erdvès už ideologinių debatų, svarstančių apie kalbų tarptautinę svarbą. Ji atkreipia demesi $\mathfrak{i}$ tai, kaip turi evoliucionuoti paradigmos ir kaip jos sąveikauja su tarptautinių kalbų propagavimu Lietuvoje, tarp jų šalia kitų, svarbių savo ịtaka, ir ispanų kalbos, pastaraisiais dešimtmečiais, sekant „tarptautinès kalbų reikšmės indeksu“, išsakytu Markeso De Tamaron'o (Marqués de Tamarón, 1992) bei pritaikytu Chaimès Otero 1995-aisiais (1995), ispanų kalbai priskiriančio antrają vietą. Lietuvoje ispanų kalba vis labiau populiarejja, tačiau dẻl ịvairių priežasčių, tokių kaip mokytojų trūkumas ir mokymo politikos nebuvimas, vis dar stebime deficitinę pasiūlą, labai ribojančią jos pasiekiamumą moksleiviams ir studentams, priešingai nei Lietuvoje „tradicinèmis“ laikomos užsienio kalbos, tokios kaip anglų, rusų, vokiečių, prancūzų. Kaip teigiama „Kalbų mokymo politikos apraše“ (Kalbų mokymo politikos aprašas, 2006), ispanų kalba labiau studijuojama aukštosiose mokyklose, pvz., Klaipèdos universitete, Lietuvos aukštojoje jūreivystès mokykloje (LAJM) ir neformaliojo mokymo įstaigose. Sabaliauskienè straipsnyje (2012) sako, kad ispanų kalba yra tarp populiariausių užsienio kalbų, o besimokantieji šios kalbos kasmet sudaro apie 10 proc. visų užsienio kalbų besimokančių studentų. Šios autorès atliktas tyrimas atskleide, kiek yra svarbu mokytis ispanų kalbos. Ji teigia, kad greta lietuvių kalbos vartojamos ir kitos (dažniausiai rusų ir anglų) kalbos, o ši daugiakalbystė susiformavo dẻl įmonių ekonominių ryšiu su užsienio partneriais, naujų sudètingų technologijų taikymo, būtinybès naudotis technologine dokumentacija užsienio kalbomis ir kt. (Dobelienè, 2007, 20). Ranonytè teigia, kad pastaroji atsirado dèl konkrečių specialybių darbuotojų vartojamų kalbų ịvairovès, tarp vadybos ir administravimo sričių specialistų (Ranonytè et al. 2007), studentams keliamų kalbos / kalbų mokèjimo reikalavimų. Iš to matyti, kad dažniausiai darbdaviai prašo mokèti 
anglų, rusų, vokiečių, lietuvių (retai - prancūzų) kalbą. Pranašumu laikomas gebėjimas bendrauti ne viena užsienio kalba, pageidaujamas retesnių kalbų mokèjimas. Kalninytė A. (2011) pastebi, kad po Lietuvos nepriklausomybès atkūrimo ir dar labiau nuo to laikotarpio, kai Lietuva pradèjo sparčiai prisijungti prie Europos Sąjungos ekonomikos sistemos, globalizacija ir tarptautinè prekyba lẻmé ịvairių skirtingo dydžio ir struktūros verslo organizacijų ịsitvirtinimą Lietuvoje. Verslo srityje dirbantiems žmonėms prireikẻ kalbų, padedančių vykdyti tarptautinę prekybą: pvz.: steigti filialus, užmegzti ryšius, derètis dèl finansinių reikalavimų, darbo sąlygų, prekybos vystymo, ieškoti su kuo bendradarbiauti, surasti tinkamiausius tiekejjus, klientus ir t. t. Taigi, i kalbą pradèta žiūrèti kaip ị vieną svarbiausių konkurencingo verslo aspektų, turinčių didžiulę galią. Kyla klausimas, pagal kokius veiksnius reikia pasirinkti užsienio kalbą ir ją mokèti tam, kad ji efektyviai padètų būti kompetentingu darbo rinkoje tiek Lietuvoje, tiek ir kitur.

Aktualumas. Šiandieną Lietuvoje ir beveik visur kitur užsienio kalbų mokèjimas yra vienas svarbiausių reikalavimų darbo rinkoje. Dabartinès Lietuvos įmonès ir tarptautinès kompanijos, kurios turi filialų Lietuvoje, vis labiau reikalauja, kad jų darbuotojai moketų užsienio kalbas. Užsienio kalbos mokymas Lietuvoje ypač reikalingas dèl to, kad tarptautinès kompanijos kuria savo atstovybes Lietuvoje, viešasis sektorius dirba su visa Europos Sajunga (ES), švietimo įstaigos plètoja bendradarbiavimą su viso pasaulio mokymo ịstaigomis. Iš praktikos galima pasakyti, kad didžioji dalis darbdavių tikisi, jog ir eilinis darbuotojas, kuris dirba arba ieško darbo, jau moka mažiausiai dvi užsienio kalbas: anglų kalbą puikiai ir dar vieną užsienio kalbą bent susikalbèjimo lygiu.

Ekonominiu lygmeniu Italija, Ispanija, Prancūzija ir Vokietija laikomos svarbiomis Lietuvos prekybos partnerėmis, o tai esą lemia ir šių šalių kalbomis kalbančių darbuotojų poreikị mūsų šalyje. Taip pat kiek rečiau mokomasi lenkų, ispanų, italų, portugalų kalbų. Lietuvoje pastebèta, kad didèja rusų kalbos mokymosi poreikis. Greičiausiai jis atgimè su jaunaja karta, kuri nesimoke šios kalbos mokykloje, beveik nesusiduria kasdieniniame gyvenime, todèl rusiškai nemoka. „Kad ir kaip bebūtų, rusų kalba - vienos didžiausių šalių, vis didinančios įtaką pasaulyje, ir pačios didžiausios lietuvių kaimynès šalies, su kuria Klaipėda daugiausiai susijusi geografiškai ir demokratiškai, o jūrininkams tradiciškai yra pagrindinè kalba. Kalbant konkrečiai apie LAJM, galima teigti, kad apie 50 \% studentų moka rusų kalbą kaip gimtają ir yra dvikalbiai.“

Tačiau, jei pažvelgtume ị pasaulines tendencijas, jau keletą dešimtmečių iš eilès dominuojančią vietą tarp visų užsienio kalbų užima lingua franca - anglụ kalba. Nepaisant to, pasak Servanteso instituto, kalbančiųjų ispanų kalba skaičius sparčiai auga, o ispanų kalba (po anglų) yra antroji kalba pasaulyje, kurios mokomasi kaip užsienio kalbos.

Problema. Klaipedos mieste, tiksliau aukštosiose mokyklose, yra iki šiol siūloma ispanų kalbą mokytis kaip pasirenkamają užsienio kalbą; Lietuvos jūreivystės mokykloje jau 5 metus, o Klaipėdos universitete dar šiek tiek seniau - déstomasis 
dalykas. Dirbant šiose mokymosi įstaigose pastebèta, kad tiek dauguma studentų, tiek ne kalbų specialistų dėstytojų dar nesupranta, kam reikia mokytis tokios gana retos Lietuvoje kalbos kaip ispanų. Vis dar kyla probleminis klausimas, kiek yra itakinga ispanų kalba jūroje arba jūrinès prekybos sektoriuje. Koks raštingumo indèlis studentams i jų profesinę ateitị bus išmokus ispanų kalbą?

Tyrimo objektas - Lietuvos aukštoji jūreivystès mokykla. Lietuvos tarptautinè užsienio prekyba.

Tyrimo tikslas - atskleisti ispanų kalbos, kaip tarptautinès kalbos pasaulyje, svarbą Lietuvoje.

Nustatyti, kokius pagrindinius aspektus reikia akcentuoti, kad ispanų kalbą būtų reikalingiau mokytis už kitas užsienio kalbas.

\section{Tyrimo uždaviniai:}

1. Išsiaiškinti, kokia yra dabartine ispanų kalbos svarba ir situacija pasauliniame kontekste, apibrēžti, koks santykis yra tarp tarptautinių kalbos poreikių besikeičiančiame globaliame pasaulyje.

2. Apibrèžti, kokie veiksniai turètų nulemti, kad ispanų kalbos mokymasis Lietuvoje, kaip jūrinèje valstybèje, būtų sureikšmintas atsižvelgiant ị geopolitines ir geoekonomines perspektyvas ir akademines kompetencijas bei Klaipėos regiono poreikius.

3. Apklausti studentus ir išanalizuoti jų nuomonę dèl ispanų kalbos mokejjimo ir poreikio jūrinių profesijų sektoriui.

\section{Tyrimo metodai:}

Šiame straipsnyje remiamasi naujausia 2018 metų statistine ataskaita apie ispanų kalbą pasaulyje, vertinga Cervanteso instituto - vieno iš pagrindinių ir oficialių šaltinių - medžiaga, kuri atnaujinama kasmet nuosekliai atliekant tyrimus, taip pat taikant analizès metodą nagrinèjama kita mokslinè literatūra, leidžianti gilintis ir suprasti ugdymo(si) veiksnių sąvokų konceptų analizę. Studentų apklausa raštu leidžia ištirti ugdymosi veiksnius, turinčius įtakos būsimųjų profesionalu atsakomybės formavimuisi. Analizuojant pasaulines tarptautiškumo tendencijas, galime išskirti pagrindinius išorinius ir vidinius veiksnius, kurie padès nustatyti ispanų kalbos svarbą Klaipėdoje plètojamam verslui ir jūrinių profesijų mokymui.

\section{Aspektai, padedantys apibrèžti kalbos svarbą}

Kalbos svarba yra konceptas, kuris provokuoja diskusijas ir netgi priešpriešas. Svarbu suvokti, kad lingvistiniu ir antropologiniu požiūriu visos kalbos yra vienodai svarbios, o kai kalbama apie reliatyvią svarbą iš karto iškyla etniniai, rasiniai ar identiteto skirtumai. Geriausiu atveju kalbos vertinimas iš socialinio, kultūrinio, politinio ar ekonominio konteksto gali išprovokuoti debatus, kurie iš esmės yra ideologiniai. (Moreno, 2015) Tačiau žinant, kad kuri nors kalba gali paveikti sociumą, 
pasidaro aišku, kokią edukacinę ir mokymo politiką būtina priimti. Yra daugybė galimų kiekybinių ir kokybinių modelių tam pačiam klausimui išspręsti, palyginus pagal svarbą ir išrūšiavus daugiau nei 7000 pasaulyje egzistuojančių kalbų. Verta pažymèti kelis iš jų, kurie neatsiejami nuo tyrimo. Ekologinis modelis remiasi lingvistinès pasaulio ịvairovės žemėlapio sudarymu (Greenberg, 1956; Lieberson, 1964). Genetinis modelis veda paraleles tarp genetinių pasaulyje paplitusių grupių ir didžiujų kalbinių šeimų (Cavalli-Sforza, 1996). Etnolingvistinis modelis dèmesị sutelkia ị lingvistinị vitališkumą (Giles et al., 1977). Intergeneracinis modelis skaičiuoja interrupcijos indeksą tarp atskirų ta pačia kalba kalbančių kartų (Lewis, Simons y Fennig, 2013). Dar kitas modelis - koncentrinis modelis - kalbas skirsto $i$ koncentruotas orbitas ir remiasi kalbos koncentracija. David'as Gradol'is (2006) teigia dar kitokị modelį, kuris peržengia nacionalinès ir regioninès kalbos ribas ir susitelkia ị vadinamąsias ,,didžiąsias kalbas “ (Gradol, 1997). Visi šie modeliai svarsto aspektus, kuriuos ne visada galime įvertinti skaičiais ir dèl to negalime pateikti tikslių ataskaitų. Tačiau bet kokiu atveju didžioji dalis tų modelių, išskyrus genetinį, užima svarbią vietą.

Taigi panašu, kad nèra taip paprasta nustatyti konkrečią analizès formą remiantis dviem konceptais: kas yra būdinga tarptautinei kalbai ir kokie iš tikro yra veiksniai, kurie lemia kalbos svarbą? Bernard'as Comrie (1987) kalba apie tokius objektyvius kriterijus kaip kalbančiųjų skaičius, kalbos oficialumas valstybëje, vartojimas kiekvienoje šalyje ir literatūrinè tradicija. Etnoligvistai išskiria tokius kalbu skirtybių aspektus kaip demografinè ịvairovè, kalbos institucinis statusas (Giles ir kt., 1977). Dar kituose moksliniuose tyrimų darbuose svarbiausiais ateityje išliksiančiu kalbų indikatoriais išskiriama dešimt: eksportas iš šalies, verslo kalbos, valdžios teikiami verslo prioritetai, atsarginès strateginès rinkos, diplomatiniai ir saugumo prioritetai, lingvistinis gyventoju pasirinkimas, kelionių kryptys, edukaciniai valdžios prioritetai, ta kalba kitose šalyse kalbančiujų lygis ir jos paplitimas internete (Tinsley ir kt., 2013).

Tikriausiai per specifinio indekso konsekvenciją yra efektyviausias būdas iš tiesų interpretuoti kalbinę pasaulio sistemą; interpretacijos forma, kur remiamasi argumentais, projektuojamais ị tarptautinès politikos ir teritorinio vieneto tarptautinius santykius, globalią kultūros politiką, diplomatiją, technologijas ir t. t. Marqués'as de Tamarón'as $(1990,1992)$ suveda visus kintamuosius ị vieną formulę, kur kalbos svarbumas (IL) yra lygus kiekvieno komponento (In) sandaugos su apibrěžto specifinio ponderacijos veiksnio (Wn) skaičiaus, padalinto iš ponderacijos veiksnių sumos (Wn), dalmeniui, kuris visada yra lygus 1 . IL visada bus skaičius tarp 0 ir 1, kur juo labiau jis artès prie 1, juo labiau tarptautiniu mastu bus svarbi kalba.

$$
\mathrm{IL}=\frac{\Sigma(\operatorname{In} \times W n)}{\Sigma W n}
$$


Kalbančiuju gimtaja kalba skaičius. Kalbantieji sudaro socialinius kalbų pamatus ir yra neatsiejami nuo generacinès transmisijos mechanizmo. (Bréton, 1979) Kalbos oficialumas ar kooficialumas. Tai yra bazinis elementas tam, kad sužinotume tarptautinę kalbos, kaip komunikacijos instrumento, lingvistiniame-kultūriniame bloke vertę ir kad išmatuotume jos potencialo vertę tarptautinèse organizacijose. Žmonijos raidos indeksas. Pagal Jungtinių Tautų Raidos programą kiekvienais metais yra paskelbiamas trimis veiksniais paremtas indeksas: kiekvienos šalies nacionalinè renta, gimstamumo apžvalga, alfabetizacija ir vidutinè mokymosi trukmè. Eksporto apimtys. Eksportas yra ekonominis veiksnys, tiesiogiai susijęs su šalies rentabilumu. Eksportuojanti šalis turi daugiau galimybių paveikti kitas teritorijas ir patraukia daugiau dèmesio tiek dèl grynai ekonominių, tiek dẻl kitų vertybinių priežasčių, tokių kaip kultūrinès, socialinès, materialinès. (Moreno, 2015) Vertimu produktyvumas. Dèl kitų šalių susidomèjimo atsiradęs produktas, norint išsiversti ị savo kalbą intelektualią ir technologinę medžiagą, kurią sukuria labiau išsivysčiusios šalys, inovacijų ir technologijų pionieriai, o tai nulemia tiek humanistinès aplinkos, tiek socialinès bei mokslinès-technologinès aplinkos pokyčius. Oficialūs tarptautiniu organizaciju, tokiu kaip ES ar JTO, dokumentai. Kalbai tapus oficialia kalba didelèje sistemoje, tokioje kaip Jungtinès Tautos, ji igauna diplomatinio ir institucinio svorio simptomų. Ir iš tikrujų ispanų, prancūzų, arabų, rusų ir kinų mandarinų bei anglų kalbos yra diplomatijos kalbos. Tuo tarpu anglų kalba yra ES darbinè kalba, o prancūzų, vokiečių ir ispanų iggyja antrinių komunikacijos kalbų statusą.

1 lentelè. Tarptautinis kalbų svarbumo indeksas (2014)

\begin{tabular}{|c|c|c|c|c|c|c|c|}
\hline Kalba & $\begin{array}{l}\text { Kalbantieji } \\
\quad(m \ln .)\end{array}$ & $I D H$ & Šalys & $\begin{array}{c}\text { Eksportas } \\
\text { (mln. JAV doleriu) }\end{array}$ & Vertimai & $O N U$ & IL 2014 \\
\hline anglu & 360 & 0,667 & 46 & 4516567 & 1264943 & 1 & 0,418 \\
\hline kinu & 955 & 0,764 & 3 & 2759500 & 14065 & 1 & $\mathbf{0 , 3 5 2}$ \\
\hline ispanu & 470 & 0,732 & 21 & 1294041 & 54535 & 1 & 0,332 \\
\hline arabu & 295 & 0,639 & 24 & 1902330 & 12407 & 1 & 0,302 \\
\hline rusu & 155 & 0,788 & 2 & 530700 & 103587 & 1 & 0,289 \\
\hline prancūzu & 74 & 0,536 & 27 & 1820359 & 225745 & 1 & 0,273 \\
\hline vokiečiu & 89 & 0,897 & 6 & 2288390 & 208060 & 0 & 0,261 \\
\hline malaju & 77 & 0,842 & 3 & 828491 & 217 & 0 & 0,259 \\
\hline korejjiečiu & 76 & 0,812 & 2 & 663562 & 4701 & 0 & 0,245 \\
\hline japonu & 125 & 0,911 & 1 & 792900 & 29241 & 0 & 0,244 \\
\hline italu & 60 & 0,897 & 2 & 783700 & 69538 & 0 & 0,24 \\
\hline švedu & 9 & 0,904 & 2 & 250300 & 39852 & 0 & 0,233 \\
\hline portugalu & 215 & 0,554 & 8 & 859826 & 11566 & 0 & 0,172 \\
\hline hindi & 310 & 0,554 & 1 & 309100 & 1512 & 0 & 0,165 \\
\hline Iš viso: & 3270 & & 148 & 19599766 & 2039969 & & \\
\hline Ponderacija & 0,25 & 0,25 & 0,25 & 0,09 & 0,09 & 0,07 & \\
\hline
\end{tabular}

Lentelèje pateikiama Francisko Moreno (Francisco Moreno, 2015) apskaičiuota kriterijų indeksacija ir ją atitinkantys ponderacijos skaičiai ir koeficientai. 
Reikia pažymėti, kad 1 lentelèje pateiktų kalbų mokosi ir jas vartoja komunikacijai 46 proc. ir daugiau žmonijos, turint galvoje, kad jos sudarymo metu gyveno daugiau kaip 7 milijardai žmonių. Iš analizuojamų kalbų (iš viso 14) i sąrašą patenka kalbos, kurios 25 šalyse yra oficialios, jomis kalba didžiausios šalys eksportuotojos bei aštuonios kalbos, iš kurių pastarajj dešimtmetį buvo gausiausiai verčiama ị kitas kalbas: anglų, prancūzų, vokiečių, rusų, italų, ispanų, švedų ir japonų. Indeksas IL rodo, kad pirmauja anglų kalba, bet ją sparčiai vejasi kinų ir ispanų kalbos.

\section{Ispanų kalba ir šiandieninis pasaulis}

Apžvelgėme skaičius, surinktus apie kalbas Servanteso instituto (2018). Pagal statistiką, ispanų kalba yra kalba, kuria šiandien kalba daugiau nei 577 milijonai pasaulio gyventojų, o tai implikuoja, kad 2018 m., skaičiuojant gimtakalbius + ribotos kompetencijos + ispanų kalbos studentus (7,6 proc. žmonių bendruomenès), šis skaičius ịkopia į antrą vietą tarptautinèje pasaulio komunikacijoje.

Virtualiajame pasaulyje ispanų kalba yra trečioji iš labiausiai vartojamų. 2017 metais 8,1 proc. interneto bendravo ispaniškai. O tai reiškia, kad ispanų kalbos vartojimas gerokai padidejo, nes $2000 \mathrm{~m}$. sudare tik 1,7 proc. Ispanų kalba yra antroji labiausiai vartojama Vikipedijos, feisbuko ir tviterio naršytojų ir paskyru turètojų kalba.

Žiūrint iš mokslinių ir kultūrinių kalbos vartojimo pozicijų, ispaniškai kalbančios šalys sparčiai aktyvejja nuo 1996 m. Pagrindinè veikeja mokslo sklaidos srityje išlieka Ispanija, ją po truputị vejasi Meksika. Beveik 75 proc. mokslinès produkcijos ispanų kalba išsidalina tarp trijų principinių tematinių sričių: socialinių, medicinos mokslų bei menų ir humanitarinių mokslų.

Pagal šalis, Ispanija yra trečioji šalis pasaulyje pagal knygų eksportą. Mokslinè ir techninè ispanų kalba yra antroje vietoje tarptautiniu mastu (Plaza y Bordons, 2006). Ji yra trečioje vietoje, tačiau gerokai nutolusi nuo anglų ir prancūzų pagal mokslinių žurnalų leidybą ir straipsnių publikacijas.

\section{Ispanų kalba - rinkos kalba}

Ispanų kalba, kaip tarptautinė kalba, yra homogeninè ir geografiškai kompaktiška: didžioji dalis šalių, kalbančių ispaniškai, užima tęstines teritorijas; ispanakalbè teritorija turi labai aukštą komunikatyvinį indeksą - ispanų kalba galima susikalbėti dvidešimt vienoje pasaulio šalyje; tai - ekspansijos kalba; tarptautinès kultūros kalba (Moreno ir Otero, 2007b). Tarptautinis kalbos bruožas taip pat apibrèžia ir jos įtaką ekonomikai. Vienas svarbiausių ir svariausių indikatorių, parodančių, kad ispanų kalba - tarptautine kalba, yra, be abejonès, ịtaka tarptautinei komercijai. Iš esmès disponuojant ta pačia kalba, tarsi dvigubinami abipusiai tarpvalstybiniai prekybiniai mainai. Ispanų kalbos atveju, bendra kalba abipusę komerciją tarp ispanakalbių šalių padidina keturis kartus (García ir Jiménez, 2015:203). Be viso 
to, bendra kalba yra svarbiausias kintamasis paaiškinti ir plètoti dvišalę komerciją tarp šalių, kalbančių ispaniškai, ir anglosaksų (Jiménez ir Narbona, 2011), visiškai nepriklausomai nuo to, kad anglų kalba tarptautiniame versle yra lingua franca.

Pagal apklausos, atliktos Ispanijoje, duomenis, trečdalis eksporto ịmonių teigia, kad dirbant su skirtingos kalbos šalimis, stengiantis adaptuoti eksportuojamus produktus, prarandama daugiau nei 1 proc. pajamų. Be to, 37 proc. nuo pardavimo kainos paliekami reklaminems kampanijoms pritaikyti ir rinkodarai. Ir priešingai, 79 proc. eksporto įmonių tiki, kad vien tai, kad šalis, ̣̣ kurią eksportuojama, kalba ispaniškai, palengvins jų tarptautinius veiksmus. Ir ši kvota siekia net 84 proc. ispaniškų įmonių, ịkurtų už Ispanijos ribų (García Delgado ir Jiménez, 2015).

Lygiagrečiai su tarptautiniu ir ekonominiu kalbos koncepto lyginimu stovi ir teiginys „kalba - kaip rinka“. Pastarasis teiginys inkorporuoja tokius aspektus, kaip kalbos mokymas ir asocijuoti rinkodaros veiksniai (ispanų kalbos mokymas užsieniečiams, leidiniai, skirti mokyti ispanų kalbos, ir pan.); lingvistinès paslaugos; kalbos technologijos (įrankiai ir informaciniai ištekliai, skirti ispanų kalbos mokymui).

Šioje mūsų analizès vietoje reikètų grịžti prie Klaipèdos ir pastebėti, kad Klaipėda kaip uostamiestis turi ypač kreipti dėmeș̣ ị kalbų, tarp jų ir ispanų, tikslingą populiarinimą, nes tai daro ir darys didžiulę ịtaką ekonominei jos raidai ir stiprins prekybinius ryšius su ispaniškai kalbančiais regionais, kuriuose progresas itin ryškus ir kurie atveria tiesiogines galimybes verslui.

\section{Ispanų kalbos mokymo galimybės ir ateities perspektyvos}

Globalizacija ipareigoja stiprinti tarptautines kalbas ir šiandien nurodo penkias kalbų vertinimo tendencijas: kalbų skaičiaus pasaulyje mažèjimą, migracijos įtaką, didejjantị turizmo mastą, antrujų ir trečiųjų užsienio kalbų mokymąsi bei internetinès erdvès naudojimą (Garrido, 2017). Be abejonès, anglų kalba yra labiausiai studijuojama pasaulyje kalba, o antrają vietą kartu su prancūzų ir kinų mandarinų kalbomis dalijasi ispanų kalba. 2018-aisiais daugiau nei 21 milijonas mokinių ir studentų visame pasaulyje mokèsi ispanų kaip užsienio kalbos. Konkrečiau - 21815 280. Šis skaičius gautas susumavus 107 šalyse besimokančiųu skaičiu. Skaičius apima visus kalbos mokymo lygius, taip pat ir neformalujj mokymą. Reikètų pažymèti, kad tose šalyse, kur anglų kalba yra gimtoji, ispanų kalba yra beveik vienareikšmiškai studijuojama kaip užsienio kalba. JAV ir Didžiojoje Britanijoje kalba, kuriai suteikiama didžiulè reikšmè, yra ispanų. Jungtinès Amerikos Valstijos turi ir svarbų istorinį veiksnį - kolonizaciją, lemiančią ispanakalbių imigraciją ir tendencingą jų skaičiaus augimą.

Kaip teigia Pew Research Center mokslininkai, JAV gyvena 55,2 milijonu lotynų amerikiečių, iš kurių didžiajai daugumai ispanų kalba yra gimtoji. Jie sudaro 17 proc. šalies gyventojų. Be to, dar didesnę dali sudaro likę gyventojai, kuriems ispanų kalba yra antroji kalba. Prognozuojama, kad 2060 metais JAV bus po Meksikos antroji pagal dydị ispaniškai kalbanti šalis pasaulyje. Pagal JAV statistikos de- 
partamento prognozes, 2060-aisiais 119 milijonų JAV gyventojų bus ispanakalbiai. Tai reiškia, kad tai sudarys 28,6 proc. JAV populiacijos, arba kad ispaniškai kalbès kas trečias šalies gyventojas (JAV statistikos departamentas, 2015).

Anglų kalbos sklaida ypač suaktyvejjo per Antrajji pasaulinį karą ir tęsiasi iki šiol. Tačiau ispanų kalba ją vejasi vis didejjančiu pagreičiu. Tai susiję ne tik su ispanų bendruomenès didejjimu Amerikoje. Jei galvoje turèsime tik rytų kalbas, ispanų kalba užima po anglų antrają vietą. English Next yra mokslinis tyrimas, atliktas British Council institucijos ir taip pat prognozuojantis stiprią ispanų ir anglu kalbų konkurenciją netolimoje ateityje (Graddol, 2006). Kitas autorius teigia, kad 2050-aisiais ,nepaisant to, kad ir nèra kalbų čempionų lygos, ispanų kalba ateityje bus labiausiai vartojama mokymui nei anglų“ (Cruz, 2006).

Jungtinès Karalystès atveju ispanų kalbai taip pat piešiama šviesi ateitis. Tai galima suprasti iš $2017 \mathrm{~m}$. publikuoto British Council informacinio pranešimo, kuriame aptariami būsimieji lingvistiniai poreikiai eksportui, komercijai, augančioms rinkoms, diplomatiniams ir saugumo prioritetams. Ten pat prognozuojama, kad vienas iš veiksnių, kurių imsis valdžia, bus kalbos politika, siekianti išvengti monolingvizmo ir priimti ispanų kalbą kaip antrają švietimo sistemos kalbą (Board ir Tinsley, 2017).

Europos Sajungos erdveje ispanų kalbos studijos yra apibrěžtos politikos, skatinančios multilingvizmą, ir ịkvėptas Europos institucijų, ịsikūrusių Prancūzijoje, Švedijoje ir Danijoje, ir lemiančių, kad ispanų kalba, kaip antroji užsienio kalba, būtų studijuojama antrosios pakopos studijų metu. Kita vertus, tas faktas, kad ispanų, vokiečių ir prancūzų kalbos bus darbinèmis Europos Komisijos kalbomis, suponuoja šių kalbų mokymą (Fernandez Vítores, D. 2011). Ir aiški politinė nuostata, kad ispanų kalba turi sklisti diplomatiniu Europos lygmeniu taip, kaip anksčiau buvo tarp didžiosios gyventojų daugumos platinama anglų kalba. Politikams atrodo, kad rinkejjai juos vertina ir už tai, kad jie moka savo žinias parodyti kai kuriomis aplinkybėmis, net atsisakydami gimtosios kalbos, ir ypač kad moka anglų kalbą (Sánchez ir Tremosa, 2013: 105).

Ispanų kalba yra labiau pasklidusi kalba Amerikoje nei Europoje, todèl, kaip nurodo Anson'as (2007), ji yra Europoje penktoji po vokiečių, anglų, prancūzų ir italų pagal kalbančiujų skaičių. Taip nutiko dèl pavėluoto Ispanijos įsitraukimo ị bendrą rinką. Nepaisant to, ispanų kalba yra labiausiai populiarejanti per trumpą laiką, nes gimtakalbių ispanų pasauliniu mastu sparčiai daugèja, tuo tarpu prancūzų, vokiečių, anglų, rusų ir netgi kinų mažèja, ispanus lenkia tik arabai (Moreno y Otero, 2007).

Ispanų kalbos plitimo fenomenas fiksuojamas ne tik Vakaruose. Ne per seniausiai Kinijoje ispanų kalba buvo ịvesta kaip privalomoji užsienio kalba vidurinèse mokyklose: jau treji metai, kai ispanų kalbos mokymo bandomoji programa, kai mokiniai turi dvi savaitines pamokas (lygiai tiek pat, kiek ir anglų kalbos), vykdoma visose Pekino mokyklose. Netolimoje ateityje ši praktika bus taikoma visoje šalyje. 


\section{Ispanų kalba ir jūros sektorius}

Plètojantis bendrai tarptautinei prekybai, svarbią vietą užima jūriniai keliai ir transportas. Būtent prekybinių ryšių plettojimas jūra ir jūros transportas yra pagrindinès LAJM tyrimų ir profesinio formavimo sritys. Mokykla stengiasi prisitaikyti prie globalioje jūrinejje rinkoje vykstančiu procesų ir perprasti šiuose procesuose dalyvaujančių dalyvių pagrindinius vaidmenis, o atsižvelgdama ị tai, nusibrěžti gaires, kad paruoštų ateičiai savo ugdytinius, kurių žinios būtų paremtos ne tik naujausiomis teorijomis, bet ir atvertu kuo platesnes praktines galimybes. Tam ypač pasitarnauja prieš kelerius metus įdiegtas privalomas ispanų, kaip antrosios kalbos, mokymas. Vienas iš veiksnių, nulemusių tokị aukštosios mokyklos vadovybės sprendimą, buvo ispanų kalbos pripažinimas oficialia darbine kalba daugelyje tarptautinių organizacijų, Europos Sajungos institucijoje ir Jungtinių Tautų Organizacijoje. Ne mažiau svarbu pažymèti, kad Tarptautinè jūrinè organizacija (IMO) ispanų kalbą yra patvirtinusi viena iš šešių oficialių kalbų. Jei apžvelgtume visose šiose organizacijose vartojamas oficialias kalbas, pastebetume, kad ispanų kalba beveik visais atvejais pagal vartojimo dažnumą tiek darbiniuose susitikimuose, tiek dokumentuose yra antroji po anglų kalbos, ir tik po jos eina prancūzų, vokiečių ir kitos kalbos. Be to, reiktų pastebèti, kad ispanų kalba per gana trumpą laiką ,pergalèjo" tokias kalbas kaip arabų ar rusų, kurios yra varžomos limituotos tarptautinès projekcijos, taip pat, nepaisant didžiulio kalbančiųų skaičiaus, kinų kalba vis dar neturi tarptautinio statuso (Fernandez Vitores D., 2014). Orts mano, kad ispanų kalba, nepaisant to, kad yra tarptautine, iš tikrujų eksporto erdvejje vis dar yra lenkiama anglų kalbos (Orts, 2006). House (House, 2013) tvirtina, kad vienos kalbos, šiuo atveju - anglų, konsolidacija jūrinio transporto dokumentuose yra skolinga istorinei situacijai, kai Didžioji Britanija kartu su JAV ir kitomis anglakalbèmis valstybėmis po Antrojo pasaulinio karo užèmè pagrindines jūrinės ekonomikos pozicijas. House taip pat kaip vieną iš priežasčių nurodo ir technologinių procesų evoliuciją, kuriai plisti ir keistis informacija reikèjo vienos kalbos, ir čia pat pažymi, kad būtent dèl to šiandien IMO anglų kalbą yra patvirtinusi kaip techninę ir informacinę jūrinio transporto kalbą, idant pasauliniu lygiu šiame sektoriuje nekiltų jokių nesusikalbẻjimų ir būtų saugus informacijos perdavimas ir prièmimas. Tačiau kitose jūrinès prekybos srityse kasdien jaučiama vis daugiau multikultūriškumo ir multilingvizmo apraiškų. Tarp jūrų kompanijų agentų, pagalbinio transporto operatorių vis labiau ịsigali pagalbiné arba papildoma kalba, t. y. ispanų. Todèl tai būtina žinoti ir tos kalbos mokytis.

Kitas sektorius, neatsiejamas nuo jūros ir jūrinių kelių, yra turizmas. Jis apima viešbučių verslą, turizmo industriją ir turistinị bei privatų jūrų transportą. Tai tradiciškai priklausanti Ispanijai ir ispanakalbèms jūrinėms valstybėms sritis, kuria remiasi daugelio tokių šalių ekonomika, tuo pačiu sudarydama svarbią tarptautinès ekonomikos dalị. Jūrinis turizmas Ispanijoje yra integruota sistema, leidžianti taikyti gerąsias praktikas ir jūrinio turizmo patirti peržengiant klimatines zonas. 
Pasak pasaulinès turizmo organizacijos, Ispanija dèl šios praktikos yra antroji po Prancūzijos, labiausiai turistų lankoma šalis pasaulyje - 81,8 milijono lankytojų per 2018-uosius, kas sudare 58,6 milijono euru pajamų. Ne ką prastesniais rodikliais pasižymi kitos ispaniškai kalbančios šalys: Meksika ir Argentina. Visos šios didelès organizacijos administracija yra ịsikūrusi Madride, o jos oficialios kalbos yra ispanų, anglų, prancūzų ir rusų.

Iš to, kas buvo pasakyta anksčiau, žinome, kad ispanų kalba užsigarantavo istoriškai komercijos kalbos vietą. Iš čia seka klausimas, kokios šiandien yra sąlygos ir galimybės bendrauti su ispaniškai kalbančiomis šalimis ir koki potencialą galètume išnaudoti tam, kad pagerintume prekybą ir priimtume švietimo ir ugdymo strategijas ir nustatytume prioritetus, susijusius su ispanų kalba Lietuvos moksle ir versle, ieškodami naujų prekybinių ryšių ir logistikos galimybių pasitelkus kalbą.

2 lentelè. Eksportas, importas pagal ir teritorijas $2018 \mathrm{~m}$. sausis-gruodis

\begin{tabular}{|c|c|c|c|c|c|c|c|}
\hline $\begin{array}{c}\text { Vieta } \\
\text { nr. }\end{array}$ & Šalis & $\begin{array}{c}\text { Eksportas, } \\
\text { mln. euru }\end{array}$ & Procentai & $\begin{array}{c}\text { Vieta } \\
\text { nr. }\end{array}$ & Šalis & $\begin{array}{c}\text { Importas, } \\
\text { mln. euru }\end{array}$ & Procentai \\
\hline 1 & Ispanija & 307,8 & 1,08640413 & 1 & Ispanija & 566,6 & 1,830508923 \\
\hline 2 & Meksika & 25,2 & 0,089118668 & 2 & Argentina & 29,8 & 0,096270049 \\
\hline 3 & Argentina & 15,4 & 0,054419683 & 3 & Ekvadoras & 16,2 & 0,052310804 \\
\hline 4 & Čile & 12,6 & 0,044538019 & 4 & Čile & 14,9 & 0,048241269 \\
\hline 5 & Panama & 10,5 & 0,037080398 & 5 & Meksika & 12,2 & 0,039350984 \\
\hline 6 & $\begin{array}{c}\text { Dominikos } \\
\text { Sandrauga }\end{array}$ & 3,1 & 0,010887587 & 6 & Kosta Rika & 5,3 & 0,017029864 \\
\hline 7 & Urugvajus & 2,7 & 0,009693372 & 7 & Peru & 3,1 & 0,009882456 \\
\hline 8 & Peru & 2,4 & 0,008445341 & 8 & Urugvajus & 1,4 & 0,004653565 \\
\hline 9 & Kolumbija & 2,3 & 0,008280027 & 9 & Venesuela & 1,1 & 0,003509009 \\
\hline 10 & Kuba & 2,2 & 0,007909976 & 10 & Bolivija & 1,0 & 0,003382738 \\
\hline 11 & Venesuela & 1,3 & 0,004726477 & 11 & Nikaragva & 0,9 & 0,002857385 \\
\hline 12 & Kosta Rika & 1,2 & 0,004118888 & 12 & Kolumbija & 0,7 & 0,002232697 \\
\hline 13 & Ekvadoras & 1,0 & 0,003540306 & 13 & Hondūras & 0,1 & 0,000381074 \\
\hline 14 & Paragvajus & 0,7 & 0,002353839 & 14 & Dominikos & 0,1 & 0,000297928 \\
\hline 15 & Bolivija & 0,4 & 0,001406946 & 15 & Paragvajus & 0,0 & 0,000124805 \\
\hline 16 & Salvadoras & 0,2 & 0,000770439 & 16 & Salvadoras & 0,0 & $9,45521 \mathrm{E}-05$ \\
\hline 17 & Nikaragva & 0,2 & 0,000603297 & 17 & Panama & 0,0 & $1,19268 \mathrm{E}-05$ \\
\hline 18 & Hondūras & 0,1 & 0,000226529 & 18 & Kuba & 0,0 & $4,60339 \mathrm{E}-06$ \\
\hline & suma & $\mathbf{3 8 9 , 4}$ & $\mathbf{1 , 3 7 4 5 2 3 9 2 2}$ & & & $\mathbf{6 5 3 , 5}$ & $\mathbf{2 , 1 1 1 1 4 4 6}$ \\
\hline & & & & & & \\
\hline
\end{tabular}

$2018 \mathrm{~m}$. Tarptautinès prekybos ir užsienio investicijų statistikos skyrius Lietuvos statistikos departamentas. 
Apžvelgę LR užsienio reikalų ministerijos (2018) pateiktą balansą tarp eksporto ir importo ( 2 lentelè), galime teigti, kad Ispanija 2018 metais buvo penkta partnere Europos Sajungoje, 19 pasaulyje pagal eksportą iš Lietuvos ir 16 pagal i Lietuvą importuojamus produktus. Liūdna, tačiau prekyba su Lotynų Amerika lieka antrame plane, o skaičių nuotolị atitinka geografinis atstumas tarp Lietuvos ir Lotynų Amerikos (LA), skiriantis nuo mūsų ispaniškai kalbančius strateginius partnerius. 2018-aisiais eksportas į LA tesudare 1,4 proc. viso eksporto, įskaitant Ispaniją. Vis dèlto importas yra didesnis už eksportą ir neturi didelès reikšmès. Jis sudaro vos 2,1 proc. bendro importo, įskaitant Ispaniją.

Šiandienos Lietuvos naudojamos komercijos strategijos yra kur kas labiau orientuotos ị artimuosius kaimynus, ir to rezultatai - akivaizdūs. Dèl to atitinkamai ir kalbos, kurios būtų naudingos tarptautiniam ekonominiam bendradarbiavimui, yra rusų, vokiečių, lenkų ir latvių. Didžioji dalis prekių, kurias Lietuva eksportuoja ar importuoja $\mathfrak{i} /$ iš Lotynų Amerikos, keliauja per kitas valstybes tarpininkes. Būtu kur kas naudingiau, jei šiais atvejais būtų dirbama tiesiogiai, apsieinant be tarpininkų ir sudarant tiesiogines sutartis, tačiau panašu, kad kol kas nèra politinio intereso tam ne tik teoriškai, bet ir dèl to, kad nėra kultūrinių sąsajų ir bendrų užmojų.

Aptariant geografinę kalbančių šalių situaciją, galima pastebėti, kad tiek Ispanija, tiek Lotynų Amerika yra pagarsèjusios kaip privilegijuotos, tradiciškai puoselèjančios prekybą jūra šalys, išskyrus Boliviją ir Paragvajų (nejūrinès valstybės), kurios pagrindinę veiklą telkia uostuose ir kurių uostai yra tuo pačiu ir sostinès. Iš viso 46 uostai, kurie valdo 68 proc. viso pasaulio prekybos jūra ir vykdo eksportą jūrų keliais. Lygiai taip pat ir LA ir Karibai, turintys daugiau kaip 120 uostų, kurie pasižymi 1,4 proc. augimu per metus kasmet (ECLAC, 2018). Vidutiniškai šios ekonomikos, įskaitant Ispaniją, turi be galo dideli potencialą - 18 proc. grynojo vidaus produkto technologijų plètros ir globalizacijos yra susitelkusios ị stambujji tolimujų atstumų transportą, kas sąlygoja naudą ir rentabilumą ir yra esminè tarptautinès prekybos ašis transportuojant žaliavas, maisto produktus ir prekes (CEPAL, 2017). Ryšiai, saistantys LA, Aziją ir ES, sujungė šiuos regionus ir padare juos komerciškai konkurencingus. Būtent dèl to yra labai svarbu orientuoti naujas politikas ị šią rinkos nišą.

\section{LAJM studentų pirmasis įspūdis, susijęs su ispanų kalba}

Tyrimo metu buvo apklausta 250 Lietuvos aukštosios jūreivystès mokyklos (LAJM) studentų, kuriems pagal 3 mokykloje patvirtintas programas - laivavedybos, logistikos ir uostų administracijos - desstoma ispanų kalba kaip privaloma antroji užsienio kalba. Duomenys buvo renkami ketverius metus, studijuojant A1 lygi, t. y. kai kurso intensyvumas yra nuo 150 iki 180 akademinių valandų vidutiniškai, priklausomai nuo programos. Didžioji dalis apklaustųų yra 19-22 metų amžiaus ir kaip pirmają užsienio kalbą vidutiniškai moka anglų, be to, didelè dalis respondentu yra dvikalbiai - kalba lietuvių ir rusų kalbomis, kai rusų ir lietuvių kalbos jiems yra 
gimtosios. Pagrindinis apklausos tikslas buvo išsiaiškinti, kiek respondentai pažista ispanų kalbą pirmojo kontakto metu ir kiek šis pažinimas pasikeičia pradèjus mokytis. Klausimyną sudarè 7 klausimai su 4 galimo atsakymo variantais, kad galiausiai pagal pasiskirsčiusius procentus būtų išskirtos 4 atsakymų grupès.

Apklausos rezultatai parodè, kad 30 proc. respondentų, pasirinkusių daugiausiai A atsakymų, puikiai žino ispanų kalbą, suvokia, kodẻl jos reikia mokytis ir su malonumu jos mokosi, stengdamiesi maksimaliai įsiminti pamatinį ispanų kalbos kursą ir sugebėti minimaliai ja bendrauti savo būsimoje profesineje veikloje. 31 proc. respondentų, atsakydami ị septynis klausimus, pasirinko daugiausia B, ir tai rodo, kad, nors ir yra neblogai informuoti apie ispanų kalbą, tačiau kalbant apie pastarosios vartojimą būsimojoje karjeroje, nelabai suvokia jos vaidmenị ir galimybes, tačiau yra suinteresuoti išmokti ką nors naujo ir įdomaus, skirtingai nuo kitų dėstomujų dalykų turinio. Trečioji grupe, kuri sudaro 23 proc. visų apklaustujų, yra mažai motyvuoti, neturi aiškaus supratimo apie kalbą, bet sutinka, kad ilgainiui gal kažkada kur nors ją pritaikys. Galiausiai paskutine - ketvirtoji grupè - 15 proc. apklausoje dalyvavusiujjų - yra visiškai nesuinteresuoti mokytis ispanų kalbos, apie ją ne ką težino ir nemato reikalo žinoti, ir apskritai nenori mokytis.

\section{Išvados}

Nepaisant, kad yra daugybė modelių ir formų, kaip suklasifikuoti svarbiausias pasaulio kalbas, galima išskirti vieną metodą, išskiriantị kintamuosius, pagal kuriuos apibūdinamos tokios kalbos. Tai: kalbančiujų skaičius, kalbos oficialumas ir kooficialumas, žmogiškosios plètotès indeksas, eksporto apimtis, vertimų produkcija, dalyvavimas oficialioje tarptautinių organų, tokių kaip ES, JTO, veikloje ir susipažinimas su dokumentacija. Pagal šį indeksą ispanų kalba yra antroji ịtakingiausia ir svarbiausia kalba pasaulyje.

Dèl pasaulinio lygio tendencijų ispanų kalba, būdama antraja pagal svarbą ir poveikị kalba, yra patvirtinta kaip antroji užsienio kalba anglosaksų šalių, Jungtinių Amerikos Valstijų ir Didžiosios Britanijos, švietimo sistemose. Šis faktas ateityje prisidès prie bendros lingvistinės ekspansijos, tokios, kokią istoriškai patyre anglu kalba.

Atsižvelgiant $\mathfrak{i}$ darbinius poreikius, profesionalai privalo suprasti, kad, be gimtosios kalbos, būtina mokèti ne tik lingua franca, bet ir dar vieną papildomą kalbą. Lietuvoje dèl susiklosčiusių geografinių ir geopolitinių aplinkybių labiau jaučiama sąlygojanti multilingvizmą vokiečių ir rusų kalbų ekspansija. Mažai tautai, įsikūrusiai koridoriuje tarp Rytų ir Vakarų, nelieka nieko kito kaip stabiliai komunikuoti su abiem didžiosiomis kaimynèmis, tačiau nereikètų pamiršti ir globalių perspektyvų ir atsiverti naujiems horizontams pasitelkus ispanų kalbos mokymą.

Lietuvos aukštosios jūreivystès mokyklos studentai turi labiau pasitikèti ispanų kalba ir suprasti, kad tai - strateginè investicija, garantuojanti ir stiprinanti jų 
konkurencingumą darbo rinkoje. Akademinè visuomenè turi skatinti ir intensyvinti ispanų, kaip antrosios užsienio kalbos, mokymą, bet ir ją įtraukti ị profesinị formavimą, atsižvelgiant ị tai, kad ši kalba yra ne tik tarptautine, bet ir verslo kalba, leidžianti gerinti komercinius santykius ir turtinti rinką bendradarbiaujant su šalimis, kalbančiomis ispaniškai.

Jūrinio transporto kontekste ispanų kalba kaskart užima vis tvirtesnes pozicijas kaip potenciali komercinès pramonès ir turizmo kalba, tačiau techninès ir jūru transporto operatorių komunikacijos kalba išlieka anglų, taip garantuojant komunikaciją ir pasaulinès jūrų transporto bendruomenès saugumą.

\section{Literatūra}

1. Aldea Mundo Revista sobre Fronteras e Integración (2013) ISNN 1316 6727 / Prieiga per internetą: <https://www.redalyc.org/html/543/54335856007/.>

2. Blommaert, J.(2010). The Sociolinguistics of Globalization. Cambridge: Cambridge University Press.

3. Bobadilla, J. (2016) Perfil marítimo y logístico de América Latina y el Caribe. Prieiga per internetą: $<$ https://www.cepal.org/es/infografia/ranking-puertos-top-20-america-latina-caribe-2016>

4. British Council \& Instituto Cervantes (2011). Word by Word. The Social, Economic and Political Impact of Spanish and English. Palabra por palabra. El impacto social, económico y político del español y el inglés. Madrid: British Council - Instituto Cervantes - Santillana.

5. British Council (2013). The English Effect: The Impact of English, What it's Worth to the UK and why it Matters to the World. $<$ https://www.britishcouncil. org/sites/default/files/english-effect-report-v2.pdf.>

6. Calvet, Louis-Jean (2006): Towards an Ecology of World Languages. Cambridge: Polity Press.

7. Cavalli-Sforza, L. (1996). Gènes, peuples et langues. Paris: Odile Jacob.

8. Dobelienè, R. 2008. Sociologinio tyrimo „Kalba darbe“ apžvalga. Gimtoji kalba 4, 16-22.

9. Fernández Vítores, D. (2014). La lengua española en el sistema de las Naciones Unidas.

10. Informes del Observatorio / Observatorio Reports, 04-10. Instituto Cervantes at Harvard University

11. García Delgado, A., Jiménez, J. (2015) Lengua, empresa y mercado: ¿ha ayudado el español a la internacionalización? Madrid: Fundación Telefónica

12. Giles, H.(1977). Towards a Theory of Language in Ethnic Group Relations. London: Academic Press.

13. Graddol, D. (1997). The Future of English? London: The British Council. Londres: British Council. Prieiga per internetą: $<$ https://www.teachingenglish. org.uk/sites/teacheng/files/pub_learning-elt-future.pdf $>$ 
14. Greenberg, Joseph (1956). The Measurement of Linguistic Diversity. Language,32: 109-115.

15. House, J. (2013). English as a Lingua Franca and Translation. The Interpreter and Translator

16. Instituto Cervantes (2018). El español, una lengua viva. Informe 2018. Anuario del Instituto

17. Cervantes. El español en el mundo. Madrid: Instituto Cervantes. Prieiga per internetą: <https://cvc.cervantes.es/lengua/espanol_lengua_viva/pdf/espanol_ lengua_viva_2018.pdf $>$

18. Jiménez, J. C., Narbona, A. (2011). El español en los flujos económicos internacionales. Un instrumento de la internacionalización empresarial. Madrid: Fundación

19. Kalbos, ịvairovè, pilietiškumas. Kalbų mokymo politikos aprašas. 2006. Kalbų politikos skyrius Strasbūre. Lietuvos Respublikos švietimo ir mokslo ministerija 2004-2006. Vilnius. Prieiga per internetą: <https://www.smm.lt/uploads/ documents/Archyvas/lt_kalbospolitika/kalbu_politika_internetui.pdf $>$

20. Kalninytè, A. (2011). Ar Lietuvos įmonèms reikia daugiakalbių darbuotojų? Kalbotyra. Kaunas: Vytauto Didžiojo universitetas, ISSN 1392-1517. Prieiga per internetą: <https://www.researchgate.net/publication/305202711_Ar_Lietuvos_imonems_reikia_daugiakalbiu_darbuotoju>

21. Lewis, M., Gary, P. (2013). Ethnologue: Languages of the World. $17^{\mathrm{a}}$ ed., Dallas, Texas: SIL International : <http://www.ethnologue.com>

22. Lieberson, S. (1964). An Extension of Greenberg's Linguistic Diversity Measures». Language, 40: 526-553.

23. Lietuvos statistikos departamentas. (2012). Darbo rinkos metraštis. Vilnius: Lietuvos statistikos departamentas. Prieiga per internetą: $<$ https://www.urm. lt/uploads/default/documents/Vokietija\%20SQ\%20(2017).pdf $>$

24. Massart-Piérard, F. (2007): „Espaces linguistiques comparés: trajectoireset processus transversaux». Revue international de politique comparée." 165-192.

25. Maurais, J., Morris, M. (2003). Languages in a Globalising World. Cambridge: Cambridge University Press.

26. Moreno, F., Otero J. (1998). Demografía de la lengua española. Anuario del Instituto Cervantes. El español en el mundo. Madrid: Instituto Cervantes Arco/Libros.

27. Moreno F. (2009). Principios de sociolingüistica y sociología del lenguaje. 4a. ed. Barcelona: Ariel.

28. Moreno, F., Otero Roth, J. (1998). Demografía de la lengua española. VV. AA. El español en el mundo, Anuario del Instituto Cervantes. Prieiga per internetą: <http://cvc. cervantes.es/Lengua/anuario/anuario_98/moreno/p01.htm>

29. Moreno, F. (2011). En Word by Word. The Social, Economic and Political Impact of Spanish and English. Palabra por palabra. El impacto social, económico y político del español y el inglés. Madrid: British Council - Instituto Cervantes 
Santillana, pp. 380-381; 386-387.

30. OIM (Organización Internacional Maritima). Prieiga per internetą: http:// www.imo.org/es/KnowledgeCentre/Paginas/Translation.aspx

31. Moreno, F. (2015). La importancia internacional de las lenguas. Informes del Observatorio Observatorio Reports. ISSN: 2373-874X, Instituto Cervantes, Harvard University.

32. Orts, L. (2005). Neological Patterns in Spanish Legal Discourse; the Phenomenon of Mobbing. LSP and Professional Communication, Vol. 5, 48-59.

33. Puidokas, M. Andriuškaitė L. (2013). Klaipėdos valstybinio jūrų uosto transporto politikos analizė pozicionuojant Lietuvą kaip jūrinę valstybę. Viešoji politika ir administravimas Kaunas: Kauno technologijos universitetas. ISSN 2029-2872

34. Sabaliauskienè, R. (2012). La enseñanza de español en la universidad Vytautas Magnus: Principales tendencias. Darnioji daugiakalbystè. Kaunas: Vytauto Didžiojo universitetas, ISSN 2335-2019, e-ISS N 2335-2027. Prieiga per internetą: http://dx.doi.org/10.7220/2335-2027.1.8

35. Tamarón, M. (1992). El español, ¿lengua internacional o lingua franca?». Actas del Congreso de la Lengua Española. Sevilla: Instituto Cervantes, pp. 189-211. Prieiga per internetą: http://bit.ly/1FCLPCx

35. Tamarón, M. (1995): El peso de la lengua española en el mundo. Valladolid: Fundación

36. Tremosa, R. (2013). La decadencia de España en la Unión Europea. El

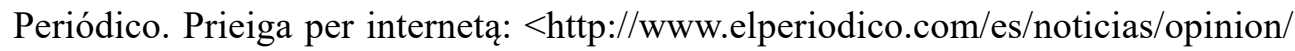
decadencia-espana-unioneuropea-por-ramon-tremosa-2361416>

37. UNWTO World Tourism Barometer - Barómetro OMT del Turismo Mundial Print ISSN: 2017 Pagina oficial de la Organización mundial del Turismo 1728-9254. Prieiga per internetą: <www.e-unwto.org/doi/pdf/10.18111/wtobarometeresp> 


\title{
THE SPANISH LANGUAGE AS A SECOND FOREIGN \\ LANGUAGE AND ITS SIGNIFICANCE \\ IN THE MARINE CONTEXT
}

\author{
Aleksas Eugenijus Kulvietis
}

Lithuanian Maritime Academy

\section{Summary}

For the last 15 years, a growing interest in the Spanish language was observed not only in the Lithuanian universities and higher education institutions but also in secondary schools and gymnasiums. In the modern world, the Spanish language has been gaining increasingly stronger positions as it has the second largest number of speakers (approx. 500 million people) globally. Spanish is the official language in 21 countries and is used in 5 oceans. It dominates not only geographical area but virtual space as well. For some, it is a beautiful and simple language, while others think that learning Spanish should enable them to discover a large cultural and exotic territory.

The article analyses the latest statistical data about the Spanish language and its expansion. The aim is to illustrate dominant language policies and the influence of the Spanish language in the global context. Is the popularity of Spanish related to the extent of global trends taking into consideration the fact that currently over 22 million students learn this language? Is this the result of the latest fashion wave? There is also a matter of English as a dominant global language. In all social, political and economic areas, the communication is linked to the English language and its terminology, new technologies and communication medias helping to spread English culture-related lifestyle which impose and dictate how to learn, speak and follow certain standards. Thus, the question is whether learning Spanish is necessary and meaningful. By applying the same principle, the Spanish language teaching and learning is analyzed and discussed with respect to students in study programmes related to transportation, trade and sea. Finally, the aim is to find the answer to the main motivated question: should seafarers know Spanish? Is this a sign of prestige? Is Spanish treated as an international language of seafaring? Is the last statement true?

Keywords: teaching/learning, Spanish as a foreign language, multilingualism, international language. 


\section{AUTORIAUS LYDRAŠTIS}

Autoriaus vardas, pavardė: Aleksas Eugenijus Kulvietis

Mokslo laipsnis ir vardas: ispanų kalbos specialistas, kalbotyros magistrantas.

Darbo vieta ir pareigos: Klaipedos universiteto Humanitarinių ir ugdymo mokslų fakulteto Europos kalbų katedros asistentas, LAJM bendrų dalykų ispanu kalbos lektorius.

Autoriaus mokslinių interesų sritys: tarpkultūrinis ugdymas, daugiakalbyste, kalbotyra (fonetikos ir semantikos lyginamasis tyrinejjimas)

Telefonas ir el. pašto adresas: + 370614876 22;

el.p.aekulvietis@gmail.com

\section{AUTHOR'S COVER LETTER}

Author's name and surname: Aleksas Eugenijus Kulvietis

Academic degree and name: Master of Linguistics, Spanish Language Specialist

Workplace and position: Assistant Professor, Department of European Languages, Faculty of Science, Klaipeda University

Author's research interests: multilingualism, linguistics (comparative study of phonetics and semantics)

Telephone and e-mail address: +370 61487 622; aekulvietis@gmail.com 